Berkala Ilmu Perpustakaan dan Informasi, Vol. 16, No. 2, Desember 2020, Hal. 211-223 DOI: 10.22146/bip.v16i1.510

ISSN 1693-7740 (Print), ISSN 2477-0361 (Online)

Tersedia online di https://journal.ugm.ac.id/v3/BIP

\title{
Pengaruh kompetensi dan motivasi kerja terhadap kinerja pustakawan di Perpustakaan Kabupaten Badung
}

\author{
Ni Putu Premierita Haryanti ${ }^{1}$, I Putu Suhartika ${ }^{2}$ \\ ${ }^{1,2}$ Program Studi D3 Perpustakaan, Fakultas Ilmu Sosial dan Ilmu Politik, Universitas Udayana \\ ${ }^{1,2}$ Jalan P.B. Sudirman (Kampus Sudirman), Denpasar-Bali, 80232 \\ e-mail:premierita@unud.ac.id
}

Naskah diterima: 20 Juli 2020, direvisi: 12 September 2020, disetujui: 29 September 2020

\begin{abstract}
ABSTRAK
Pendahuluan. Penelitian ini memfokuskan pada kompetensi, motivasi, kinerja dan pengalaman kerja pustakawan di Perpustakaan Kabupaten Badung. Penelitian ini menganalisis peran moderasi pengalaman kerja terhadap kompetensi, motivasi dan kinerja pustakawan di perpustakaan tersebut.

Metode penelitian. Metode penelitian ini yaitu kuantitatif dengan pendekatan deskriptif. Teknik pengambilan sampel yang digunakan adalah total sampling dengan jumlah 39 orang terdiri dari pustakawan sekolah, perguruan tinggi dan perpustakaan kabupaten dengan menggunakan kuesioner, observasi dan wawancara.

Data Analisis. Dalam penelitian ini menggunakan teknik analisis regresi moderasi (Moderated Regression Analysis/MRA).

Hasil dan Pembahasan. Hasil dalam penelitian menunjukkan bahwa pengalaman kerja tidak memoderasi secara positif dan tidak signifikan mengenai hubungan antara kompetensi dan motivasi kerja terhadap kinerja pustakawan. Hal yang berkaitan dengan kompetensi, motivasi dan kinerja pustakawan perlu lebih ditingkatkan terutama dalam penguasaan bahasa asing dan penulisan karya tulis ilmiah bidang kepustakawanan.

Kesimpulan dan Saran. Pengalaman kerja tidak memoderasi pengaruh kompetensi dan motivasi kerja terhadap kinerja pustakawan sehingga pihak manajemen perpustakaan perlu mengevaluasi kembali kompetensi pustakawan.
\end{abstract}

Kata kunci: kompetensi; motivasi kerja; kinerja pustakawan; pengalaman kerja; perpustakaan

\section{ABSTRACT}

Introduction. This paper focuses on competence, motivation, performance and work experience of librarians in Badung Regency Library. The paper aims to examine the role of moderation work in the library.

Methodology. A quantitative descriptive was applied using total sampling as the sampling technique. There were 39 librarians in this study from schools, universities and district areas. Questionnaires, observations and interviews were used as data collection methods.

Data Analysis. Data analysis technique used was Moderated Regression Analysis (MRA).

Results and Discussion. The results showed that working experience did not moderate positively and there was no significant relationship between competence and work motivation on librarian performance. Aspects related to competency, motivation and performance of the librarians need to be increased, particularly, English skills and academic in the field of librarianship.

Conclusion. Work experience does not affect competency and work motivation on the performance of the librarians so that the library management needs to re-evaluate the competency of the librarian.

Keywords: competency; workmotivation; librarian performance; work experience; library 


\section{A. PENDAHULUAN}

Perpustakaan merupakan bagian dari lembaga informasi memiliki fungsi yang besar dalam perkembangan dunia informasi saat ini. Selain itu, kondisi informasi juga berbanding lurus dengan kemajuan teknologi. Untuk mengoptimalkan hal tersebut, perpustakaan perlu memiliki sumber daya manusia yang berkualitas dalam hal ini kompetensi kustakawan sebagai salah satu penentu keberhasilan kegiatan perpustakaan. Kompetensi tersebut diantaranya mencakup keterampilan komunikasi, kemampuan dalam menggunakan teknologi informasi, serta kemampuan interpersonal dan intrapersonal. Pustakawan yang memiliki kompetensi yang berkualitas akan berpengaruh terhadap kinerja pustakawan. Kompetensi pustakawan yang tinggi akan berdampak kepada kualitas kinerja yang baik sehingga tujuan di perpustakaan dapat tercapai lebih optimal. Selain kompetensi pustakawan, untuk menghasilkan kinerja yang baik juga dipengaruhi dari motivasi pustakawan yang berasal dari dalam dan dari luar pustakawan. Motivasi yang timbul dari dalam diri pustakawan sangat membantu dalam meningkatkan kinerjanya. Namun kondisi yang terjadi di perpustakaan, motivasi yang ada dalam diri pustakawan belum maksimal. Oleh karena itu, untuk mengoptimalkan hal tersebut diperlukan dukungan dari pihak manajemen perpustakaan sebagai pihak eksternal yang memberikan motivasi bagi pustakawan.

Pustakawan menjadi faktor penentu keberhasilan penyelenggaraan perpustakaan. Kinerja pustakawan yang baik tidak hanya diukur dari kompetensi dan motivasi kerja, namun juga dipengaruhi oleh pengalaman kerja. Semakin lama pustakawan bekerja pada bidangnya maka pengalaman kerja pustakawan tersebut semakin bertambah. Hal tersebut juga memberikan dampak terhadap kinerja pustakawan. Indikator pengalaman kerja pustakawan salah satunya adalah masa kerja. Pengalaman kerja pustakawan yang tinggi akan mempengaruhi kompetensi dan berdampak pula kepada kinerja pustakawan. Semakin tinggi pengalaman kerja pustakawan maka memberi kecenderungan kompetensi pustakawan semakin bertambah sehingga kinerja pustakawan menjadi lebih optimal. Selain itu, pengalaman kerja yang tinggi juga memengaruhi motivasi kerja pustakawan sehingga berdampak pula kepada optimalisasi kinerja pustakawan.

Kajian mengenai evaluasi kinerja pustakawan sejauh ini telah cukup banyak dilakukan seperti penelitian yang dilakukan oleh Jabbar (2015) dan Hasan (2018). Namun kajian yang dilakukan bersifat umum, dalam hal ini hanya membahas mengenai kinerja pustakawan yang dihubungkan dengan peningkatan pelayanan perpustakaan. Nurfaidah menyatakan bahwa bagian dari kinerja yang perlu dimiliki oleh perpustakaan didasarkan pada sikap dan perilaku yang baik dengan berorientasi kepada kebutuhan pengguna perpustakaan (pemustaka). Selain itu, pustakawan perlu memiliki pemahaman diri mengenai teknis/cara dalam memberikan kepuasan kepada pemustaka sedangkan larabeng menemukan bahwa terdapat gap antara kinerja pustakawan dengan kepuasan pelanggan. Selain itu, penelitian lain dilakukan oleh Hasan (2018) yang membahas mengenai pendidikan dan pelatihan sebagai upaya peningkatan kinerja pustakawan. Dalam hal ini kompetensi pustakawan menjadi salah satu hal yang penting dan memiliki tanggung jawab yang kompleks untuk meningkatkan kinerja.

Sejauh ini kajian mengenai kinerja pustakawan lebih dikaitkan pada kegiatan pelayanan atau kegiatan yang berorientasi terhadap pengguna perpustakaan (pemustaka). Untuk menganalisis kinerja pustakawan sesungguhnya ada banyak faktor yang mempengaruhi dan hal tersebut dapat bersumber dari diri pustakawan seperti kompetensi, motivasi dan pengalaman kerja yang dimiliki. Selain faktor-faktor yang mempengaruhi hal tersebut, teknik analisis yang digunakan khususnya pada metode kuantitiatif di bidang perpustakaan sejauh ini lebih dominan menggunakan analisis regresi linier sederhana atau dengan menguji dua variabel yaitu satu variabel bebas dan satu variabel terikat. Berkaitan dengan hal tersebut, maka penelitian mengenai kinerja pustakawan yang dikaitkan 
dengan kompetensi, motivasi kerja dan pengalaman kerja perlu dilakukan. Dalam studi ini, menggunakan beberapa teori yang membahas secara spesifik mengenai variabel kinerja pustakawan, kompetensi, motivasi kerja dan pengalaman kerja dengan menggunakan analisis MRA (Moderated Regression Analysis) diharapkan akan memperoleh keterbaruan terkait dengan penelitian ini.

Berdasarkan uraian tersebut di atas, pentingnya penelitian ini dilakukan untuk mengetahui dan mengevaluasi kualitas pustakawan di perpustakaan wilayah Kabupaten Badung yang diukur dari kompetensi, motivasi dan pengalaman kerja yang dimiliki sehingga nantinya diharapkan penyelenggaraan perpustakaan dapat berjalan dengan optimal. Permasalahan yang diungkap dalam penelitian ini adalah bagaimana pengalaman kerja memoderasi kompetensi dan motivasi kerja terhadap kinerja pustakawan di perpustakaan Kabupaten Badung?

\section{B. TINJAUAN PUSTAKA}

Beberapa kajian mengenai kinerja pustakawan telah dipaparkan pada penelitianpenelitian sebelumnya. Ada beberapa penelitian yang berkaitan dengan kajian ini yaitu "kinerja pustakawan dalam meningkatkan layanan perpustakaan Mesjid Al-Markas Al-Islami Makassar" (Jabbar, 2015) Dalam penelitian ini difokuskan kepada kinerja pustakawan untuk meningkatkan pelayanan, yang dimana kinerja merupakan aktivitas yang telah dilakukan oleh pustakawan di perpustakaan seperti melayani pemustaka dengan baik, menyediakan koleksi yang memadai, termasuk menata ruangan untuk menarik minat berkunjung. Berbicara mengenai kinerja pustakawan sesungguhnya ada beberapa faktor yang mempengaruhi seperti kompetensi yang dimiliki, motivasi kerja serta pengalaman kerja.

Selain itu, penelitian sejenis dilakukan oleh Hasan (2018). Dalam penelitian ini dibahas mengenai faktor-faktor yang memengaruhi kinerja pustakawan. Adapun faktor yang memengaruhi kinerja secara umum adalah kemampuan dan motivasi. Kemampuan (ability) dibedakan menjadi kemampuan potensi dan kemampuan reality. Selain itu, faktor motivasi berasal dari perilaku seorang pegawai saat bekerja. Jadi kedua penelitian di atas, hanya membahas mengenai kinerja pustakawan yang dikaitkan terhadap pelayanan di perpustakaan dan faktor-faktor yang mempengaruhi kinerja sedangkan dalam penelitian ini tidak hanya dapat dipergunakan untuk mengkaji bidang pelayanan namun dapat dipergunakan untuk menganalisis kinerja di perpustakaan.

Kajian sejenis juga dipaparkan oleh Saidat \& Sunmade (2019) mengenai "Staff Motivation as Correlates of Job Performance of Library Staff in Osun State University, Osogbo, Nigeria". Dalam penelitian ini disebutkan bahwa kinerja memiliki korelasi dengan motivasi staf. Ada beberapa faktor yang memotivasi staf perpustakaan seperti tunjangan, pekerjaan, penghargaan dan lain-lain sehingga akan meningkatkan kinerja pustakawan.

\section{Kinerja Pustakawan}

Kinerja pustakawan merupakan komponen penting dalam perpustakaan. Pencapaian sebuah tujuan organisasi sangat bergantung dari kinerja sumber daya manusia dalam hal ini pustakawan. Kinerja pustakawan yang tinggi akan mengakibatkan tujuan-tujuan di perpustakaan dapat tercapai lebih optimal. Kinerja atau Job Performance dapat didefinisikan mengenai sejauh mana seseorang memenuhi persyaratan pekerjaan formal dan mampu menyelesaikan tugas yang diberikan (Lee \& Lee, 2020). Kinerja merupakan hasil kerja yang dicapai untuk setiap pekerjaan yang berfungsi selama periode waktu tertentu(Wu et al., 2019). Selain itu, kinerja merupakan tindakan, perilaku yang melibatkan karyawan atau atau yang memberikan kontribusi pada tujuan organisasi (Ratia \& Tuzlukaya, 2019).

Ada delapan faktor umum mengenai kinerja diantaranya: a) keahlian khusus pekerjaan, merupakan hasil kerja yang menjadi tugas inti untuk pustakawan seperti kegiatan pengumpulan informasi, pengolahan koleksi (klasifikasi, katalogisasi), pelayanan koleksi hingga perawatan koleksi di perpustakaan. Keahlian khusus atau pekerjaan utama ini 
menjadi hal yang paling utama untuk menghasilkan kinerja yang optimal di perpustakaan. Pustakawan sudah seharusnya dapat menjalankan keahlian khusus pekerjaan ini dengan sebaik-baiknya; b) kemahiran tugas non pekerjaan khusus atau pekerjaan utama, merupakan hasil kerja yang menjadi tugas tambahan bagi pustakawan selain dari tugas inti pustakawan seperti membuat karya tulis ilmiah di bidang kepustakawan dan aktif menjadi narasumber dalam pertemuan ilmiah; c) komunikasi tertulis dan lisan, komunikasi menjadi salah satu hal penting yang mempengaruhi kinerja perpustakaan. Secara umum kegiatan komunikasi yang berkaitan dengan pengguna perpustakaan dilakukan pada bagian pelayanan. Komunikasi dapat menjembatani antara kebutuhan pengguna dengan kegiatan di perpustakaan. Oleh karena itu, kegiatan komunikasi perlu dilakukan secara maksimal tidak hanya dengan pengguna perpustakaan melainkan dengan tim perpustakaan agar tujuan perpustakaan dapat tercapai secara maksimal; d) adanya sebuah usaha, hal yang mendasari tercapainya kinerja yang optimal di perpustakaan salah satunya adalah usaha. Pengembangan sebuah perpustakaan harus dilandasi dengan usaha yang maksimal untuk mengoptimalkan tujuan di perpustakaan. Usaha-usaha tersebut dapat berupa peningkatan kualitas sumber daya manusia, perbaikan sistem di perpustakaan, peningkatan manajemen di perpustakaan, dan lain-lain; e) upaya mempertahankan kedisiplinan, merupakan salah satu hal yang utama untuk mencapai kinerja yang optimal. Segala aktivitas yang terdapat di perpustakaan harus diikuti oleh disiplin dari setiap karyawannya. Disiplin dalam hal ini seperti datang tepat waktu, menyelesaikan seluruh pekerjaan di perpustakaan sesuai dengan waktu dan hasil yang baik, pelayanan yang prima, dan lain-lain; f) menjaga kinerja rekan dan tim, merupakan salah satu bentuk kerjasama yang dibangun antara individu dengan tim yang ada di perpustakaan untuk bersama-sama mencapai kinerja yang optimal di perpustakaan. Kinerja yang baik di perpustakaan tidak hanya dibentuk oleh satu pustakawan melainkan seluruh sumber daya manusia di perpustakaan. Oleh karena itu, setiap anggota di perpustakaan perlu bersinergi untuk mencapai kinerja yang maksimal di perpustakaan; g) kepemimpinan, menjadi salah satu faktor yang mempengaruhi kinerja perpustaaan. Kepemimpinan yang baik akan menciptakan kinerja yang maksimal di perpustakaan karena kepemimpinan diibaratkan sebagai nahkoda yang menjalankan sebuah organisasi dalam hal ini perpustakaan. Kepemimpinan menjadi salah satu bagian dari manajemen perpustakaan. Oleh karena itu, seseorang yang menjadi pemimpin di perpustakaan diharapkan memiliki kemampuan kepemimpinan yang baik dalam menjalankan kegiatan di perpustakaan, memiliki kompetensi yang tinggi dan mampu mengetahui apa yang menjadi tujuan dan kebutuhan organisasi; h) manajemen/administrasi, menjadi salah satu komponen yang mempengaruhi kinerja organisasi. Manajemen dalam setiap lembaga di perpustakaan berbeda-beda karena hal tersebut dipengaruhi oleh berbagai faktor seperti, kondisi sumber daya manusia, kondisi lingkungan di perpustakaan, sarana dan prasarana, dll. Oleh karena itu untuk menciptakan manajemen yang berkualitas diawali dari kemampuan sumber daya manusia yang baik di perpustakaan dalam merancang sebuah sistem organisasi yang ada di perpustakaan. Faktor-faktor umum mengenai kinerja yang telah disebutkan diatas perlu diikuti oleh kompetensi dan motivasi sumber daya manusia serta pengalaman kerja yang dimiliki. Jadi dapat disimpulkan bahwa kinerja pustakawan merupakan sebuah hasil kerja atau kontribusi yang diberikan dari pustakawan dalam menjalankan tugas-tugas yang terdapat di perpustakaan. Kinerja yang dimiliki pustakawan nantinya akan berdampak kepada kinerja organisasi dalam hal ini perpustakaan.

\section{Pengalaman Kerja}

Dalam sebuah organisasi, pengalaman kerja menjadi faktor yang memengaruhi keberlangsungan organisasi khususnya dalam kegiatan perekrutan karyawan. Dimana kondisi yang umum terjadi bahwa penerimaan sumber daya manusia dalam sebuah organisasi lebih 
memprioritaskan tenaga kerja yang telah memiliki pengalaman. Hal tersebut dikarenakan seseorang yang telah memiliki pengalaman kerja umumnya memiliki keterampilan lebih tinggi dibandingkan seseorang yang belum memiliki pengalaman kerja. Selain itu, seseorang yang memiliki pengalaman kerja juga mengalami proses pembelajaran yang lebih banyak. Pengalaman memiliki sebuah makna yang ditafsirkan melalui siklus aktifitas berkelanjutan yang mengalir dari mengamati, membuat dan berimprovisasi yang melibatkan seseorang/aktor yang merespon lingkungan sesuai dengan makna yang mereka anggap. Oleh karena itu dalam sebuah organisasi, pengalaman kerja dapat dihasilkan secara aktif antara individu dan organisasi dengan merancang lingkungan kerja mereka sendiri, membuat keputusan sendiri dan menentukan posisi diantara individu dan organisasi lain yang mengambil bagian dalam lingkungan yang sama (Asik-Dizdar \& Esen, 2016)

Dalam sebuah organisasi, pengalaman kerja menjadi salah satu tolak ukur dalam perekrutan sebuah organisasi serta melihat kemampuan dan kinerja karyawan. Pengalaman kerja dipengaruhi oleh beberapa faktor. Pengukuran pengalaman kerja dapat diukur dari masa jabatan (tenure) yang berhubungan dengan waktu dan tingkatan kerja di suatu organisasi. Secara umum, pengukuran pengalaman kerja diukur melalui lama kerja/masa kerja, jenjang jabatan/masa jabatan dan tingkat pengetahuan serta keterampilan. Pengalaman kerja yang tinggi umumnya berbanding lurus dengan tingkat keterampilan dalam bekerja. Masa kerja pustakawan mendukung pustakawan dalam meningkatkan kompetensi di perpustakaan jika diikuti oleh motivasi dalam meningkatkan keterampilannya melalui proses belajar dan mengikuti serangkaian pelatihan yang ada di perpustakaan.

\section{Kompetensi}

Kompetensi adalah seperangkat pengetahuan, fitur dan keterampilan yang dibutuhkan seseorang untuk menyelesaikan suatu kegiatan dalam pekerjaan tertentu (El Asame \& Wakrim, 2018). Dalam hal ini, seseorang yang memiliki kompetensi yang baik jika mampu menggerakkan pribadi dan lingkungannya dengan sumber daya yang ada untuk melakukan tugas dalam situasi tertentu. Selain itu, kompetensi yaitu perpaduan dari pengetahuan, keterampilan dan sikap (Mihaljevic, 2015). Dalam kaitannya dengan pustakawan, kompetensi merupakan keterampilan dan kemampuan pustakawan dalam menjalankan kegiatan yang terdapat pada perpustakaan untuk mewujudkan tujuan perpustakaan.

Dalam era digital, pustakawan perlu mengembangkan kompetensinya untuk mengembangkan dan mengelola perpustakaan digital. Ada beberapa kompetensi yang perlu dikembangkan oleh Pustakawan (Khan \& Bhatti, 2017) antara lain : Kemampuan dalam menggunakan internet dan pengetahuan tentang web (termasuk navigasi, Teknik pencarian, layanan referensi virtual dan desain web), Pengetahuan tentang media teknologi, Pengetahuan tentang sistem digital termasuk perangkat lunak perpustakaan digital untuk mengembangkan konten dan perpustakaan digital

Dalam era pengetahuan ada beberapa kompetensi yang diperlukan oleh pustakawan yaitu kompetensi profesional yang meliputi keterampilan dalam pengembangan koleksi, pemrosesan koleksi, pelayanan dan keterampilan dalam pendidikan pengguna. Selain itu dalam perubahan situasi pembelajaran, keterampilan teknologi informasi khususnya penggunaan internet sangat penting bagi para pustakawan(Farooq et al., 2016).

\section{Motivasi Kerja}

Motivasi merupakan "proses" psikologis yang menyebabkan gairah, arah, sikap yang mengarah pada tujuan organisasi secara sukarela. Motivasi kerja didefinisikan sebagai motivasi yang muncul dari kesenangan yang diperoleh oleh individu dari pekerjaan dan memungkinkan untuk terlibat dalam hal-hal yang besar berkaitan dengan tugasnya secara sukarela (Bui et al., 2016). Konsep motivasi berfokus kepada memberi energi, mendorong, 
merangsang individu menuju perubahan perilaku untuk mencapai pemenuhan tujuan dan sasaran suatu organisasi (Idiegbeyan-Ose et al., 2019). Motivasi menjadi faktor penting bagi individu dan perpustakaan. Hal tersebut sebagai faktor pendorong dari perilaku professional individu dari awal hingga akhir bekerja. Selain itu, motivasi sangat penting bagi perpustakaan untuk mengoptimalkan kinerja termasuk pelayanan perpustakaan. Untuk menumbuhkan hal tersebut, pustakawan perlu memiliki motivasi yang tinggi dengan didukung oleh manajemen perpustakan yang baik karena umumnya motivasi yang dimiliki oleh pustakawan belum maksimal karena adanya stigma-stigma negatif mengenai perpustakaan yang membuat motivasi pustakawan menjadi rendah, situasi kerja yang kurang mendukung pengembangan karier yang tidak maksimal, pemberian gaji yang belum sesuai untuk memenuhi kebutuhan sehari-hari, dan lain-lain.

Motivasi kerja dalam organisasi dapat bersumber dari intrinsik dan ekstrinsik. Dalam sebuah organisasi, motivasi sangat diperlukan oleh karyawan untuk meningkatkan kinerjanya. Secara umum, indikator motivasi kerja yang terdapat dalam sebuah organisasi diantaranya adanya penghargaan (reward) untuk karyawan, bonus atau tunjangan. Ada beberapa faktor yang mempengaruhi motivasi seseorang (Khorshidi et al., 2011) diantaranya : a) penghargaan dalam finansial, yang berupa tunjangan, bonus atau insentif, dan lain-lain, b) peningkatan karier pekerjaan, c) pemberian studi lanjut/ pendidikan, d) infrastruktur tempat kerja, merupakan salah satu hal yang mendasar untuk mendukung segala aktivitas yang dilakukan oleh karyawan selama bekerja dan dapat menciptakan kenyamanan selama bekerja, e) ketersediaan sumber daya, f) manajemen yang mendukung dan g) apresiasi, merupakan salah satu bentuk dukungan dari pihak manajemen kepada individu dalam organisasi. Dalam kaitannya di perpustakaan, apresiasi terhadap pustakawan sangat penting untuk dilakukan untuk menciptakan motivasi bagi pustakawan dalam bekerja di perpustakaan.

\section{METODE PENELITIAN}

Metode penelitian yang digunakan adalah metode kuantitatif dengan pendekatan deskriptif. Penelitian ini dilakukan dengan menggunakan data yang diperoleh dari penyebaran kuesioner kepada responden. Populasi dalam penelitian ini adalah seluruh pustakawan yang terdapat di Kabupaten Badung yang terdiri dari pustakawan sekolah, pustakawan perguruan tinggi dan pustakawan di Kabupaten Badung. Adapun teknik pengambilan sampel yang digunakan adalah total sampling dengan jumlah sampel sebesar 39 orang. Alasan penggunaan teknik ini karena jumlah populasi kurang dari 100 orang, sehingga seluruh anggota populasi digunakan sebagai sampel (Sugiyono, 2007).

Pada penelitian ini, teknik pengumpulan data dilakukan melalui kuesioner, studi pustaka dan observasi. Setelah diperoleh hasil dari kuesioner yang yang telah terkumpul maka selanjutnya dibuat coding book. Kuesioner digunakan untuk melakukan perhitungan terhadap data penelitian. Perhitungan data dilakukan dengan menggunakan skala Likert untuk memberikan skor tertentu pada seluruh jawaban responden yang terdiri dari skor 5 (sangat setuju), skor 4 (setuju), skor 3 (raguragu/netral), skor 2 (tidak setuju, skor 1 (sangat tidak setuju).

Adapun analisis yang digunakan adalah analisis regresi/Moderated Regression Analysis (MRA) yang merupakan sebuah cara untuk menguji interaksi hubungan antara variabel bebas, variabel terikat dan variabel moderasi dalam analisis regresi linier berganda. Selain itu, analisis ini juga menguji hubungan antara ketiga variabel tersebut untuk mengetahui ada atau tidaknya faktor yang memperkuat atau memperlemah.

Rancangan penelitian ini diambil dari beberapa faktor-faktor yang mempengaruhi kinerja pustakawan diantaranya kompetensi dan motivasi kerja. Selain itu, terdapat faktor pengalaman kerja yang memoderasi hubungan antara pengaruh kompetensi terhadap kinerja karyawan dan pengaruh motivasi terhadap kinerja karyawan. Oleh karena itu, terdapat asumsi bahwa pengalaman kerja memoderasi 
positif hubungan antara kompetensi terhadap kinerja dan motivasi kerja terhadap kinerja. Adapun faktor-faktor tersebut digambarkan dalam bentuk rancangan penelitian seperti tercantum dalam Gambar 1 .

Adapun hipotesis dalam penelitian ini antara lain sebagai berikut:

1. $\mathrm{H}_{0}$ : Pengalaman kerja tidak memoderasi positif pengaruh kompetensi terhadap kinerja pustakawan di wilayah Kabupaten Badung

$\mathrm{H}_{1}$ : Pengalaman kerja memoderasi positif pengaruh kompetens terhadap kinerja pustakawan di wilayah Kabupaten Badung

2. $\mathrm{H}_{0}$ : Pengalaman kerja tidak memoderasi positif pengaruh motivasi kerja terhadap kinerja pustakawan di wilayah Kabupaten Badung

$\mathrm{H}_{1}$ : Pengalaman kerja memoderasi positif pengaruh kompetensi dan motivasi kerja terhadap kinerja pustakawan di wilayah Kabupaten Badung

Tahapan awal dalam analisis penelitian ini yang pertama adalah analisis regresi. Hasil pengumpulan data akan dihimpun setiap variabel sebagai suatu nilai dari setiap responden dan dapat dihitung melalui program SPSS (Statistical Package Social Science) versi 23. Selain itu untuk menguji hipotesis dilakukan dnegan menggunakan analisis MRA. Dalam analisis tersebut, dapat dilakukan dengan menguji efek moderasi dan efek utama. Tahapan kedua dalam analisis penelitian ini menggunakan uji asumsi klasik yang bertujuan untuk menghasilkan persamaan regresi moderasi yang berada pada kondisi BLUE (Best Linier Unbiased Estimation). Dalam penelitian ini, uji asumsi klasik yang digunakan adalah uji normalitas dan uji heteroskedastisitas. Pada penelitian ini tidak menggunakan uji autokorelasi karena data yang digunakan bukanlah data urut waktu (time series). Selain itu, uji multikolinieritas juga tidak digunakan karena pendekatan MRA pada model regresi moderasi dapat mengakibatkan multikolinieritas yang tinggi antar variabel independen. Tahapan ketiga yaitu uji hipotesis yang bertujuan untuk mengetahui ada tidaknya pengaruh yang dimiliki oleh masing-masing variabel dan dilakukan melalui beberapa tahapan antara lain koefisien determinasi $\left(\mathrm{R}^{2}\right)$, Uji F dan Uji T.

\section{HASIL DAN PEMBAHASAN}

Hasil penelitian ini dilakukan kepada pustakawan yang ada di wilayah Kabupaten Badung yang terdiri dari pustakawan sekolah (SD, SMP, SMA), pustakawan perguruan tinggi dan pustakawan di wilayah kabupaten Badung sebanyak 39 orang.

Dari Tabel 1. dapat dirumuskan persamaan regresi sebagai berikut:

$\mathrm{Y}=\mathrm{a}+\mathrm{bX} \mathrm{X}_{1} \mathrm{k}+\mathrm{bX}_{2} \mathrm{mk}+\mathrm{bM}_{1} \mathrm{Pk}+\mathrm{BX}_{1} \mathrm{k} \mathrm{x} \mathrm{M}+$ $\mathrm{bX}_{2} \mathrm{Mk} \times \mathrm{M}$

$\mathrm{Y}=-27,734+1,076+(-8,409)+1,384+(-$ $0,029)+0,300$

$\mathrm{Y}=-27,734+1,076-8,409+1,384-0,029+$ 0,300

Hasil perhitungan di atas menunjukkan adanya peningkatan nilai variabel terikat kinerja pustakawan sebesar 0,097 dan 0,808.

Persamaan tersebut menunjukkan bahwa tingkat signifikansi variabel $\mathrm{X}_{1}$ adalah 0,650 dan nvariabel $\mathrm{X}_{2}$ sebesar 0,508 sedangkan besarnya $\mathrm{R}$ Square adalah 0,055 . Hal ini menunjukkan bahwa R Square tersebut naik sebesar 0,019. Hal tersebut dapat meningkatkan variabel independen terhadap variabel dependen. Hasil lain menunjukkan adannya perlemahan variabel kompetensi kerja terhadap kinerja pustakawan jika dilihat secara parsial.

\section{Pembahasan Statistik Deskriptif Variabel \\ 1) Variabel Kompetensi \\ Hasil penelitian menunjukkan nilai dimensi} kompetensi pustakawan cukup tinggi. Dari hal tersebut dapat dikategorikan bahwa kompetensi pustakawan di wilayah Kabupaten Badung memiliki kompetensi kerja yang cukup baik. Dari 22 dimensi kompetensi pustakawan, dimensi kompetensi personal mengenai kemampuan membangun hubungan baik dengan rekan dan atasan memiliki nilai yang tertinggi sedangkan dimensi mengenai kemampuan mengelola emosi saat sedang bekerja memiliki nilai terendah. Oleh karena itu, kompetensi pustakawan untuk mengelola emosi 
saat sedang bekerja memiliki nilai yang rendah. Hal ini dapat disebabkan oleh beberapa faktor seperti peningkatan beban kerja, keterbatasan peralatan dalam bekerja, pengetahuan pustakawan mengenai pekerjaan di perpustakaan, ketidakpastian lingkungan kerja, ketidaknyamanan di lingkungan kerja atau faktor pribadi dalam karyawan. Oleh karena itu, penting halnya pustakawan dalam bekerja mengetahui cara mengelola emosinya saat bekerja, seperti belajar mencari solusi terhadap permasalahan yang dihadapi, tahan terhadap kritikan, mencari tahu cara mengendalikan emosi, mengenali diri sendiri, belajar mengelola waktu dan meningkatkan keterampilan bekerja, dll. Pengelolaan emosi yang baik dapat meningkatkan kompetensi pustakawan dalam bekerja sehingga kinerja pustakawan semakin baik.

\section{2) Variabel Motivasi}

Hasil penelitian menyebutkan bahwa setiap dimensi motivasi memiliki jumlah nilai yang kurang tinggi. Dari 16 dimensi motivasi pustakawan, dimensi kebutuhan keamanan mengenai pustakawan merasa aman saat bekerja di perpustakaan memiliki nilai rata-rata tertinggi sedangkan nilai rata-rata terendah yaitu dimensi kebutuhan fisiologis mengenai tunjangan fungsional yang diterima sebagai pustakawan belum mencukupi kebutuhan dasar sehari-hari. Dari hal tersebut dapat disimpulkan bahwa motivasi kerja pustakawan dalam hal kebutuhan fisiologis memiliki nilai rata-rata rendah. Hal tersebut dapat disebabkan sebagian pustakawan di wilayah Kabupaten Badung belum berstatus sebagai pustakawan tetap sehingga belum mendapatkan tunjangan fungsional. Kondisi ini perlu mendapat perhatian khususnya bagi pustakawan yang belum berstatus sebagai pustakawan tetap dalam hal pemberian tunjangan fungsional. Ada beberapa cara yang mungkin dapat diberikan bagi pustakawan yang belum memperoleh tunjangan fungsional seperti memberikan reward dalam bentuk uang bagi pustakawan yang aktif melakukan berbagai kegiatan kepustakawanan atau pengembangan perpustakaan. Oleh karena itu, pihak manajemen perlu merancang kegiatan, ukuran kegiatan serta jumlah reward yang diberikan bagi pustakawan yang belum mendapat tunjangan fungsional.

\section{3) Variabel Pengalaman Kerja}

Hasil penelitian juga menunjukkan bahwa setiap dimensi pengalaman kerja memiliki jumlah nilai yang cukup tinggi. Dari 8 dimensi pengalaman kerja, nilai rata-rata terendah adalah dimensi penguasaan terhadap pekerjaan dan peralatan mengenai pustakawan mahir dalam melaksanakan tugas yang diberikan. Pengalaman kerja yang dimiliki pustakawan belum menunjukkan kemahiran dalam melaksanakan tugas-tugas yang diberikan oleh atasan. Hal ini dapat disebabkan oleh faktor pengalaman kerja yang dimiliki oleh Pustakawan belum tinggi sehingga pustakawan belum memiliki keterampilan yang maksimal saat melaksanakan tugas-tugas yang diberikan oleh atasan. Ada beberapa hal lain yang juga memengaruhi keterampilan dan kemahiran pustakawan dalam melaksanakan tugas-tugas di perpustakaan seperti motivasi pustakawan (intrinsik dan ekstrinsik), ketersediaan sarana dan prasarana, dukungan sistem di perpustakaan, dan lain-lain.

\section{4) Variabel Kinerja Pustakawan}

Hasil penelitian menunjukkan jumlah nilai pada setiap dimensi kinerja pustakawan adalah cukup tinggi. Dari 10 dimensi kinerja pustakawan, variabel kedisiplinan mengenai pustakawan patuh terhadap tata tertib yang dibuat di perpustakaan memiliki nilai rata-rata tertinggi sedangkan variabel keterampilan mengenai penguasaan bahasa asing memiliki nilai-nilai rata terendah. Sehubungan dengan hal tersebut dapat dikatakan bahwa kinerja pustakawan perlu ditingkatkan khususnya dalam keterampilan penguasaan terhadap bahasa asing. Adapun beberapa cara yang dapat dilakukan oleh pihak manajemen perpustakaan untuk meningkatkan keterampilan pustakawan dalam berbahasa asing seperti mengikutsertakaan pustakawan dalam bimbingan belajar bahasa asing, melatih keterampilan pustakawan dengan mencoba 
mempraktekkan bahasa asing pada saat bekerja (1 hari dalam seminggu kerja), mengikutsertakan pustakawan dalam kegiatan seminar internasional, dan lain-lain.

\section{Pembahasan Statistik Inferensial}

1) Moderasi Pengalaman Kerja pada Pengaruh Kompetensi terhadap Kinerja Pustakawan

Koefisien regresi pada pengalaman kerja memiliki nilai sebesar 0,029 dengan probabilitas signifikan sebesar $0,650>$ a tabel 0,005 . Dengan demikian, pengalaman kerja tidak dapat memoderasi hubungan antara kompetensi terhadap kinerja pustakawan dan dinyatakan tidak sesuai dengan hipotesis. Hal tersebut mengandung makna bahwa pengalaman kerja yang dimiliki pustakawan tidak menjamin kompetensi yang dimiliki sehingga mempengaruhi terhadap kinerjanya. Hasil penelitian ini berbeda dengan penelitian sebelumnya yang dilakukan oleh Riyanda (2017) yang menyebutkan bahwa pengalaman kerja dapat meningkatkan kinerja karyawan. Sehubungan dengan hal tersebut di atas, dapat dikatakan bahwa penelitian tentang pengalaman kerja tidak sepenuhnya dapat meningkatkan kinerja pustakawan. Dalam hal ini, ada kecenderungan pustakawan tidak memiliki motivasi yang tinggi untuk meningkatkan kompetensinya sehingga pengalaman kerja yang dimilikinya tidak mampu meningkatkan kompetensi yang dimiliki oleh pustakawan. Selain itu, kecenderungan yang lain mengenai pengembangan karier yang terbatas diberikan oleh pustakawan sehingga pustakawan kurang mampu memaksimalkan keterampilan yang dimiliki sehingga pengalaman kerja yang tinggi tidak mampu meningkatkan kompetensi pustakawan tersebut. Kondisi ini perlu mendapat perhatian oleh pihak manajemen puncak dalam peningkatan kompetensi sumber daya yang dimiliki melalui berbagai pelatihan dan program-program yang mendukung kompetensi pustakawan sehingga semakin lama pustakawan tersebut bekerja kompetensi yang dimiliki oleh pustakawan semakin meningkat.

Pada bidang perpustakaan, belum banyak dilakukan penelitian mengenai pengalaman kerja pustakawan yang mempengaruhi kompetensi dan kinerja pustakawan. Berkaitan dengan penelitian sebelumnya yang dilakukan oleh Jabbar (2015), difokuskan kepada kinerja pustakawan untuk meningkatkan pelayanan, yang dimana kinerja merupakan aktivitas yang telah dilakukan oleh pustakawan di perpustakaan seperti melayani pemustaka dengan baik, menyediakan koleksi yang memadai, termasuk menata ruangan untuk menarik minat berkunjung. Oleh karena itu, penelitian mengenai topik ini sangat perlu dilakukan pada penelitian berikutnya. Hal ini untuk memastikan kembali mengenai pengaruh pengalaman kerja pustakawan mengenai kompetensi yang berdampak kepada kinerja pustakawan. Selain itu terdapat faktor-faktor lain diluar pengalaman kerja yang lebih memengaruhi kompetensi terhadap kinerja pustakawan. Oleh karena itu, hal ini perlu dikaji lebih lanjut dengan menggunakan faktor-faktor lain yang mempengaruhi kompetensi dan kinerja pustakawan seperti kepemimpinan di perpustakaan, kondisi internal dan eksternal di perpustakaan, motivasi pustakawan, pengembangan karir di perpustakaan, dll.

2) Moderasi Pengalaman Kerja pada Pengaruh Motivasi terhadap Kinerja Pustakawan

Koefisien regresi pada pengalaman kerja memiliki nilai sebesar 0,300 dengan probabilitas signifikan sebesar 0,508 > a tabel 0,005 . Dengan demikian, pengalaman kerja tidak dapat memoderasi hubungan antara motivasi terhadap kinerja pustakawan dan dinyatakan tidak sesuai dengan hipotesis. Hal ini memiliki kecenderungan bahwa pengalaman kerja tidak mempengaruhi motivasi pustakawan sehingga pustakawan yang memiliki pengalaman kerja yang tinggi tidak sama dengan motivasi yang dimilikinya. Hasil penelitian ini berbeda dengan penelitian sebelumnya yang dilakukan oleh Aristarini (2014) yang menyatakan bahwa pengalaman kerja dapat meningkatkan motivasi karyawan yang berdampak terhadap kinerja karyawan. Sehubungan dengan hal tersebut diatas, ada beberapa faktor yang memengaruhi seperti 
rendahhnya pengembangan kerja dan tidak adanya dukungan dari pihak manajemen untuk meningkatkan kariernya sehingga motivasi yang timbul dari dalam untuk meningkatkan motivasi kerjanya menjadi rendah. Hal ini menimbulkan konsekuensi sehingga pihak manajemen perlu memiliki perhatian yang khusus terhadap pengalaman kerja pustakawan dalam upaya peningkatan kinerja. Inovasinovasi dari berbagai pihak diperlukan dalam upaya peningkatan motivasi pustakawan. Inovasi tersebut berupa promosi, kenaikan jabatan, dan peningkatan kualitas pemberian reward.

Secara teoritis pengalaman kerja dan motivasi yang dimiliki oleh individu berpengaruh positif terhadap kinerja karyawan. Oleh karena itu, hal ini menjadi perhatian bagi pihak manajemen di perpustakaan untuk memperhatikan sejauhmana pengalaman kerja yang dimiliki oleh calon pustakawan sehingga nantinya pengalaman kerja yang dimiliki oleh pustakawan dapat meningkatkan motivasinya sehingga berdampak positif bagi pustakawan dan perpustakaan. Kecenderungan yang lain terhadap hal ini adalah pengalaman kerja bukan menjadi faktor pengaruh terbesar bagi motivasi pustakawan terhadap kinerjanya. Ini memiliki pengertian bahwa ada faktor-faktor lain yang lebih memengaruhi motivasi pustakawan untuk mengembangkan kinerjanya seperti kompetensi pustakawan, dukungan pihak manajemen, situasi perpustakaan, dan lain-lain. Selain itu, penelitian mengenai hal ini masih jarang dilakukan khususnya penelitian menggunakan analisis MRA di bidang perpustakaan. Hal ini dapat menjadi tinjauan kembali bagi penelitipeneliti selanjutnya untuk meneliti mengenai topik ini dengan dikaitkan menggunakan analisis MRA.

\section{E. KESIMPULAN}

Pustakawan sebagai salah satu aset utama yang dimiliki oleh perpustakaan memiliki peran yang penting dalam meningkatkan kualitas perpustakaan khususnya mengenai peningkatan kompetensi, motivasi dan kinerja. Kompetensi dan motivasi yang dimiliki oleh pustakawan sangat diperlukan untuk pengembangan perpustakaan khususnya kinerja pustakawan. Oleh karena itu, untuk mengoptimalkan kinerja pustakawan diperlukan pengalaman kerja sehingga berdampak positif bagi perkembangan perpustakaan. Namun, dalam penelitian ini ditemukan bahwa pengalaman kerja pustakawan di wilayah Kabupaten Badung tidak memberikan pengaruh terhadap ketiga unsur tersebut sehingga ada kecenderungan individu yang tidak memiliki pengalaman kerja yang tinggi dapat meningkatkan kompetensi dan kinerjanya dengan motivasi yang ada, begitu juga sebaliknya bahwa pustakawan yang memiliki pengalaman kerja yang tinggi belum tentu memiliki motivasi yang tinggi untuk meningkatkan kompetensi dan kinerja. Dilihat dari kompetensi yang dimiliki oleh pustakawan di wilayah Kabupaten Badung, sebagian besar sudah menguasai salah satu sistem perpustakaan berbasis open source namun belum mampu menghasilkan karya tulis setiap tahunnya. Selain itu, pustakawan di wilayah Kabupaten Badung merasa nyaman dan aman saat bekerja di Perpustakaan. Oleh karena itu, pihak manajemen/kepala perpustakaan perlu mendukung kegiatan yang ada di perpustakaan dengan cara melakukan monitoring terhadap kinerja pustakawan sehingga kesadaran dari pustakawan untuk meingkatkan kompetensinya semakin tinggi. Selain itu, pemberian kesempatan kepada pustakawan/staf untuk mengikuti pelatihan atau seminar secara intensif berkaitan dengan motivasi kerja. Dari sisi pemerintah, perlu mendapat perhatian dan dukungan untuk meningkatkan kompetensi pustakawan melalui regulasi yang berkaitan dengan kegiatan yang ada di perpustakaan termasuk aturan yang berkaitan dengan motivasi pustakawan melalui tunjangan fungsional. 


\section{DAFTAR PUSTAKA}

Asik-Dizdar, O., \& Esen, A. (2016). Sensemaking at work: Meaningful work experience for individuals and organizations. International Journal of Organizational Analysis, 24(1), 2-17. https://doi.org/10.1108/IJOA-12-20130728

Bui, H. T. M., Liu, G., \& Footner, S. (2016). Perceptions of HR practices on job motivation and work-life balance: Mixed drives and outcomes in a labor-intensive sector. International Journal of Manpower, 37(6), 1004-1023. https://doi.org/ 10.1108/IJM-12-2015-0214

El Asame, M., \& Wakrim, M. (2018). Towards a competency model: A review of the literature and the competency standards. Education and Information Technologies, 23(1), 225-236. https://doi.org/ 10.1007/s10639-017-9596-z

Farooq, M. U., Ullah, A., Iqbal, M., \& Hussain, A. (2016). Current and required competencies of university librarians in Pakistan. Library Management, 37(8/9), 410-425. https://doi.org/10.1108/LM-032016-0017

Hasan, N. A. (2018). Pendidikan dan pelatihan sebagai upaya peningkatan kinerja pustakawan. Libria, 10(1), 95-115.

Idiegbeyan-Ose, J., Opeke, R., Aregbesola, A., \& Owolabi, S. E. (2019). Relationship between motivation and job satisfaction of staff in private University Libraries, Nigeria. Academy of Strategic Management Journal, 18(1), 1-13.

Jabbar, N. (2015). Kinerja Pustakawan dalam Meningkatkan Layanan Perpustakaan Mesjid Al-Markas Al-Islami Makassar [Universitas Islam Negeri (UIN) Alauddin]. http://repositori.uinalauddin.ac.id/5693/1/Nurfaidah\%20jabba r.pdf
Khan, S. A., \& Bhatti, R. (2017). Digital competencies for developing and managing digital libraries: An investigation from university librarians in Pakistan. The Electronic Library, 35(3), 573-597. https://doi.org/10.1108/EL-06-2016-0133

Khorshidi, A., Mirzamani, S. M., \& Esfahani, H. D. (2011). Effective factors in enhancing school managers' job motivation. Iranian $J$ Psychiatry, 6(4), 151-157.

Lee, S. Y., \& Lee, S. W. (2020). Social media use and job performance in the workplace: The effects of facebook and kakaotalk use on job performance in South Korea. Sustainability, 12(10), 1-19. https://doi.org/10.3390/su12104052

Mihaljevic, J. (2015). The new competency profile of academic libraries in the function of evaluation of scientific productivity. Ekonomski Vjesnik, 2, 535-549.

Ratia, L. R., \& Tuzlukaya, S. E. (2019). The relationship of the dimensions of job satisfaction to job performance: A case study of a multinational company in Lesotho. Journal of Research in Emerging Markets, $\quad 1(3), \quad 8-19$. https://doi.org/10.30585/jrems.v1i3.356

Saidat, K. R., \& Sunmade, D. G. A. (2019). Staff motivation as correlates of job performance of library staff in Osun State University, Osogbo, Nigeria. Journal of Human Resource and Leadership, 4(3), 17-29.

$\mathrm{Wu}, \mathrm{Hu}$, \& Zheng. (2019). Role stress, job burnout, and job performance in construction project managers: The moderating role of career calling. International Journal of Environmental Research and Public Health, 16(13), 2394. https://doi.org/10.3390/ijerph16132394 


\section{DAFTAR GAMBAR}

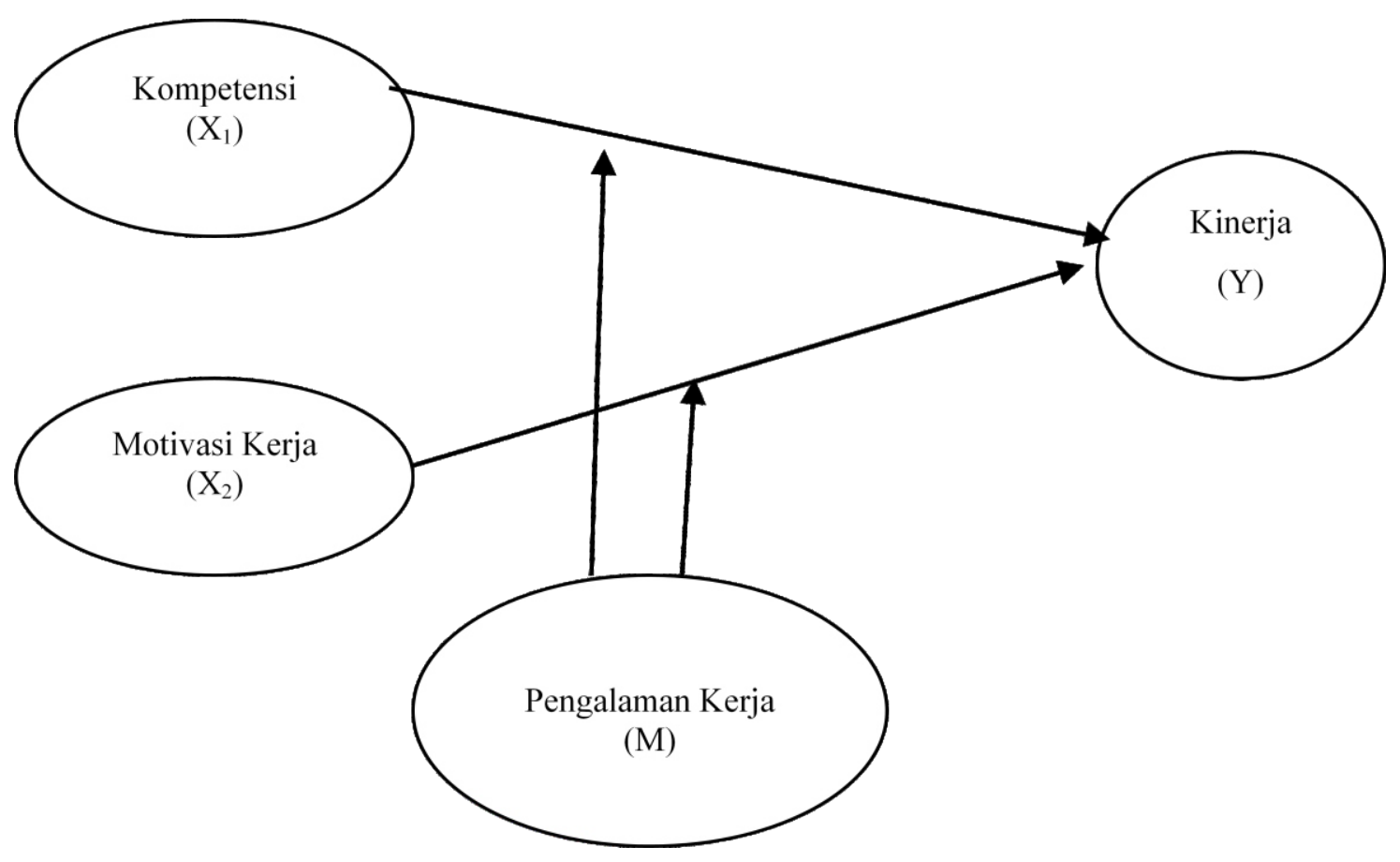

Gambar 1. Model Penelitian

\section{DAFTAR TABEL}

Tabel 1. Hasil Analisis Regresi Linier Berganda (Moderasi)

\begin{tabular}{cccccc}
\hline \multirow{2}{*}{ Variabel } & \multicolumn{2}{c}{$\begin{array}{c}\text { Unstandardized } \\
\text { Coeficient }\end{array}$} & $\begin{array}{c}\text { Standardized } \\
\text { Coeficient }\end{array}$ & T & Sig. \\
\cline { 2 - 4 } & \multicolumn{1}{c}{ B } & $\begin{array}{c}\text { Std. } \\
\text { Error }\end{array}$ & Beta & & \\
\hline Kompetensi & 1,076 & 2,051 & 1,014 & 0,525 & 0,603 \\
Motivasi Kerja & $-8,409$ & 13,780 & $-1,465$ & $-0,610$ & 0,546 \\
Pengalaman Kerja & 1,384 & 5,124 & 0,593 & 0,270 & 0,789 \\
$\quad$ Kompetensi x & $-0,029$ & 0,062 & $-1,733$ & $-0,457$ & 0,650 \\
Pengalaman Kerja & & & & & \\
Motivasi Kerja x & 0,300 & 0,448 & 1,716 & 0,669 & 0,508 \\
Pengalaman Kerja & $-27,734$ & & & & \\
\hline Constanta & 0,234 & & & & \\
R & 0,055 & & & & \\
R Square & 0,382 & & & & \\
F Hitung & 0,858 & & & & \\
Sig. F hitung & & & & & \\
\hline
\end{tabular}

Sumber: Data primer diolah, 2019 


\section{DAFTAR TABEL}

Tabel 2. Anova

ANOVA $^{a}$

\begin{tabular}{ccccccc}
\hline \multicolumn{2}{l}{ Model } & $\begin{array}{c}\text { Sum of } \\
\text { Squares }\end{array}$ & Df & Mean Square & F & Sig. \\
\hline 1 & Regression & 80.64 & 5 & 16.128 & 0.382 & $.858^{\mathrm{b}}$ \\
& Residual & 1394.591 & 33 & 42.26 & & \\
Total & 1475.231 & 38 & & & \\
\hline
\end{tabular}

a. Dependent Variable: $\mathrm{Y}_{1}$

b. Predictors: (Constant), $\mathrm{X}_{2} \mathrm{M}, \mathrm{M} 1, \mathrm{X}_{1}, \mathrm{X}_{2}, \mathrm{X}_{1} \mathrm{M}$

Tabel 3. Koefisien

Coefficients $^{\mathrm{a}}$

\begin{tabular}{|c|c|c|c|c|c|c|}
\hline & \multirow{2}{*}{ Model } & \multicolumn{2}{|c|}{$\begin{array}{l}\text { Unstandardized } \\
\text { Coefficients }\end{array}$} & \multirow{2}{*}{$\begin{array}{c}\begin{array}{c}\text { Standardized } \\
\text { Coefficients }\end{array} \\
\text { Beta }\end{array}$} & \multirow{2}{*}{$\mathbf{T}$} & \multirow{2}{*}{ Sig. } \\
\hline & & B & $\begin{array}{c}\text { Std. } \\
\text { Error }\end{array}$ & & & \\
\hline \multirow{6}{*}{1} & (Constant) & -27.734 & 167.04 & & -0.166 & 0.869 \\
\hline & $\mathrm{X}_{1}$ & 1.076 & 2.051 & 1.014 & 0.525 & 0.603 \\
\hline & $\mathrm{X}_{2}$ & -8.409 & 13.78 & -1.465 & -0.61 & 0.546 \\
\hline & $\mathrm{M}_{1}$ & 1.384 & 5.124 & 0.593 & 0.27 & 0.789 \\
\hline & $\mathrm{X}_{1} \mathrm{M}$ & -0.029 & 0.062 & -1.733 & -0.457 & 0.65 \\
\hline & $\mathrm{X}_{2} \mathrm{M}$ & 0.3 & 0.448 & 1.716 & 0.669 & 0.508 \\
\hline
\end{tabular}

a. Dependent Variable: Y1

Sumber: Data primer diolah, 2019 